HANNA ACHREMOWICZ

Forum Pedagogiczne

9 (2019) 2, cz. 1

Centrum Badawcze Stowarzyszenia Edukacji Krytycznej

Wpłynęło: 17.02.2019

Wrocław

ORDIC ID: https://orcid.org/oooo-0oo3-3398-0124

KAMILA KAMIŃSKA-SZTARK

Instytut Pedagogiki

Uniwersytet Wrocławski

ORDIC ID: https://orcid.org/oooo-ooo2-2401-9844

\title{
POMIĘDZY NAUCZANIEM KOŚCIOŁA KATOLICKIEGO A FEMINIZMEM - POTENCJAŁ EDUKACYJNY HERSTORII NA PRZYKŁADZIE ŚWIĘTEJ TEKLI
}

\author{
Ale nie byłam pewna. \\ Wcale nie byłam pewna. \\ Skąd mogłam wiedzieć, \\ czy kiedyś w przyszłości, \\ $w$ Europie czy gdziekolwiek \\ - szklany klosz znowu na mnie nie spadnie, \\ nie nakryje mnie, odkształcając moje widzenie świata.
}

Sylvia Plath, Szklany klosz

Streszczenie: Artykuł zarysowuje problematykę dialogu Kościoła katolickiego z szeroko pojętym feminizmem w kontekście autorskiej strategii edukacyjnej wyrastającej z historii (herstorii) pierwszych wieków chrześcijaństwa. Przez odwołanie do postaci mało znanej współcześnie, świętej Tekli, zostanie wzmocniona koncepcja wychowania w poszanowaniu równości płci wynikającej bezpośrednio $\mathrm{z}$ aktu stworzenia, ugruntowanej przez akt zbawienia i - jako taka - obecnej w nauczaniu Kościoła katolickiego. Będąc równe przed Bogiem, kobiety powinny mieć równe prawa w poszukiwaniu ścieżek poznania go i służenia mu. Współczesne nurty ruchu wyzwolenia kobiet odbierane są często jako wrogie nauczaniu Kościoła katolickiego. Tymczasem dzieje wczesnych wieków chrześcijaństwa wskazują na szacunek, jakim darzone były kobiety, ich niezaprzeczalną rolę w budowaniu wspólnoty, męczeństwo, determinację, mądrość i piękno. Przyjęcie takiej strategii edukacyjnej stanowi swoiste „zdjęcie klosza” (metafora Sylvii Plath), a poznanie herstorii kobiet, które budowały chrześcijaństwo, może służyć za inspirację do osobistego (nie tylko duchowego) rozwoju kobiet w Kościele katolickim.

Słowa kluczowe: herstoria; feminizm; emancypacja; dyskursy; narracje; historia mówiona. 
Podobno kobiety potrzebują obrony, ochrony przed otaczającym je światem, a ich delikatność wymaga troski. Klosz może nakładać na nie społeczeństwo, kultura, Kościół, partner. Klosz ten jednak zniekształca widzenie świata (wszak zgodnie z zasadami optyki szkło załamuje światło). Mężczyźni objaśniają mi świat, wydana w 2017 roku w Polsce książka Rebeki Solnit - która pomimo dość niszowego charakteru gatunkowego (zbiór esejów) stała się bestsellerem - tym znamiennym tytułem w lapidarny sposób podsumowuje stulecia epistemologicznej męskiej dominacji. Autorka pisze: „mężczyźni wciąż objaśniają mi świat. I jak dotąd żaden nie przeprosił mnie za błędne objaśnianie mi rzeczy, na których ja się znam, a on nie. Przynajmniej na razie. Ale, jako że zgodnie z aktualnymi statystykami mogę mieć przed sobą jeszcze nawet czterdzieści lat życia, kto wie, co może się zdarzyć. Powiedzmy, że nie wstrzymuję oddechu w oczekiwaniu" (Solnit 2017, s. 15). Klosz także zagłusza to, co się dzieje pod nim, głos spod niego jest ledwo, jeśli w ogóle, słyszalny. Kwestie równouprawnienia dotykają obu tych wymiarów: możliwości poznania świata i możliwości dzielenia się swoim jego rozumieniem. Dialog, na jaki stać tylko wolne, równe istoty. A czyż nie takimi jesteśmy przed Bogiem najwyższym? Panem i Zbawicielem?

Prezentowany artykuł zarysowuje problematykę dialogu Kościoła katolickiego z szeroko pojętym feminizmem w kontekście autorskiej strategii edukacyjnej wyrastającej z historii (herstorii) pierwszych wieków chrześcijaństwa. Przez odwołanie do postaci mało znanej współcześnie, świętej Tekli, zostanie wzmocniona koncepcja wychowania w poszanowaniu równości płci wynikającej bezpośrednio z aktu stworzenia, ugruntowanej przez akt zbawienia i - jako taka - obecnej w nauczaniu Kościoła katolickiego ${ }^{1}$. Będąc równe przed Bogiem, kobiety powinny mieć równe prawa w poszukiwaniu ścieżek poznania Go i służenia Mu. Współczesne nurty ruchu wyzwolenia kobiet odbierane są często jako wrogie nauczaniu Kościoła katolickiego. Tymczasem dzieje wczesnych wieków chrześcijaństwa wskazują na szacunek, jakim darzone były kobiety, ich niezaprzeczalną rolę w budowaniu wspólnoty, męczeństwo, determinację, mądrość i piękno. Przyjęcie takiej strategii edukacyjnej stanowi swoiste „zdjęcie klosza”, o jakim metaforycznie mówi Sylvia Plath. Przywracając pamięć o wielkich kobietach z historii chrześcijaństwa, możemy tym samym same odzyskiwać swą podmiotowość, swój głos. Wiele współczesnych kobiet nie chce, aby „mężczyźni objaśniali im świat”, a inspiracji dla rozwoju osobistego (nie tylko duchowego) poszukiwać mogą u źródeł. Nasza propozycja jest sposobem poszukiwania edukacyjnych odniesień w opowieściach $\mathrm{z}$ historii, które cechuje teraźniejsza aktualność. Problematyka kobieca, szczególnie w istotnej dla

1 Czynimy to poniżej w sposób bliższy koncepcji Jana Assmanna niż tradycyjnie pojmowanej historii. Chodzi nam tu o mnemohistorię: o przybliżenie tego, jak św. Tekla była obecna w kulturze, pamięci przez wieki i na czym polega jej potencjalna współczesna aktualność (Assmann 2018, s. 421-430). 
naszych rozważań formie tzw. herstory, posiada właśnie taką właściwość - dotyka do żywego, nie pozwala na obojętność.

Ruch feministyczny i jego postulaty nie są oczywiście żadną nowością. W dalszej części artykułu przybliżamy pokrótce dialog Kościoła katolickiego z feminizmem, w kalejdoskopie manifestacji w ramach pierwszej, drugiej i trzeciej fali. To, co stanowi dla nas specyficzną sytuację, to wzrost znaczenia postulatów równościowych dotyczących kobiet w kręgach chrześcijańskich, jak również w samym Kościele katolickim ${ }^{2}$. Omówienie nauczania Jana Pawła II w zarysowanym pokrótce kontekście historycznym stanowi tło do dalszej, autorskiej propozycji. Zakorzenienie w propozycji teoretycznej Jana Assmanna pozwala nam nie wdawać się całkowicie w dyskusje na temat tego, czy św. Tekla faktycznie sama się ochrzciła w akwarium pełnym piranii i czy prawdą jest to, że na rzymskiej arenie broniły jej lwy samice, podczas gdy samce ją atakowały. Z naszego punktu widzenia jest to zupełnie nieistotne. Znacznie bardziej inspirujące edukacyjnie są kwestie cech charakteru świętej, wyeksponowane w hagiografii: piękna, uparta (wręcz zdeterminowana, aby iść Drogą Pańską), odważna, nieugięta, mądra, nauczycielka, apostołka (James 1924).

\section{Nauczanie Kościoła katolickiego a feminizm - przegląd dyskursów}

Zrozumienie edukacyjnego fenomenu opowieści o św. Tekli wymaga poznania szerszego tła, w jakim wybrzmiewają w Kościele katolickim kobiece, nieoczywiste narracje oraz napięcia istniejące pomiędzy procesem emancypacji kobiet a jego recepcją w Kościele katolickim. Kościół zmieniał swoją narrację/nauczanie o kobietach wraz z rozwojem ruchu feministycznego. Warto przybliżyć więc najważniejsze jego postulaty i pokazać, jak rezonowały one z nauczaniem papieży. Feminizm jest i był problematyczny w odbiorze Kościoła, choć czasem w mniejszym stopniu, niż się powszechnie uważa. Podważanie dotychczasowego schematu ról płciowych i postulowanie zmian wielokrotnie było odbierane jako zagrażające porządkowi społecznemu. Choć feminizm sam jest niejednorodny, można wyróżnić w nim wiele nurtów, jak choćby liberalny, radykalny, psychoanalityczny, marksistowsko-socjalistyczny, kulturowy, egzystencjalny, postmodernistyczny, wielokulturowy, globalny i ekofeminizm, a i tak kategorie te nie oddają w pełni jego złożoności (Putnam Tong 1992, s. 7). Tym, co łączy te wszystkie nurty feminizmu, jest dążenie do różnie rozumianego równouprawnienia kobiet (Hannam 2010, s. 18). Choć narracja Kościoła katolickiego również mówi o równouprawnieniu kobiet, nadaje mu jednak pewne ramy, które można by uznać za dość konserwatywne.

Analizując historię uzyskiwania przez kobiety głosu, warto przywołać tradycje oświeceniowe i pierwsze próby wskazywania na potrzebę równego traktowania kobiet w sferze publicznej. Rewolucja francuska nie przyniosła oczekiwanych

2 Interesujący aktualny kontekst (październik 2018) stanowi akcja: „Votes for catholic women”, dostępny na: https://www.womensordination.org (otwarto: 26.10.2018). 
zmian w tym zakresie, Deklaracja praw człowieka obejmowała jedynie mężczyzn, co skrytykowała Olimpia de Gouges w tekście Les Droits de la Femme, opublikowanym w 1791 roku (Hannam 2010, s. 29-31). Mężczyzn uważano za obiektywnych, rozumnych, reprezentujących postęp, kobiety natomiast za emocjonalne, zmysłowe i nierozumne. Mary Wollstonecraft, sprowokowana wpływami rewolucji francuskiej w Wielkiej Brytanii, wydała książkę Vindication of the Rights of Woman (1792), pisząc w niej, że kobiety są równie rozumne, jak mężczyźni, jednak kultura przekonuje je, że są emocjonalne i podległe (Putnam Tong 1992, s. 22-23). Proponowała edukację i świadome macierzyństwo (Hannam 2010, s. 32-34).

Myślicielami, którzy przyczynili się do emancypacji kobiet byli John S. Mill i August Bebel. Pierwszy z nich w Poddaństwie kobiet (1869) odrzucał pogląd, zgodnie z którym kobiety są gorsze od mężczyzn. J. S. Mill głosił, że kobiety intelektualnie są równe mężczyznom i przysługują im takie same prawa (Putnam Tong 1992, s. 29).

Kluczowym postulatem dla feminizmu pierwszej fali było zdobycie praw wyborczych dla kobiet. Do jednego z największych osiągnięć należy deklaracja z Seneca Falls w stanie Nowy Jork z 1848 roku, gdzie 300 delegatów przyjęło rezolucję o prawach mężatek, rozwodach, potrzebie zatrudnienia i edukacji kobiet oraz o walce o prawa wyborcze (Hannam 2010, s. 41-46). W 1890 roku z połączenia dwóch istniejących w USA ruchów walczących o prawa wyborcze kobiet powstała organizacja National American Women Suffrage Association. Z czasem rozszerzano zakres praw kobiet, np. do edukacji i wolnych zawodów - w 1900 roku kobiety mogły pracować we wszystkich wolnych zawodach oprócz prawniczych (czyli głównie jako lekarki i nauczycielki) (Putnam Tong 1992, s. 33-35). Postulat praw wyborczych dla kobiet zrealizowano w USA w 1920 roku $^{3}$.

Na gruncie polskim idee emancypacyjne próbowały zaszczepić Eliza Orzeszkowa, Narcyza Żmichowska, Maria Konopnicka, Eleonora Ziemięcka, później Zofia Nałkowska oraz Maria Pawlikowska-Jasnorzewska. Prawa wyborcze przyznano kobietom 28 listopada 1918 roku, a w 1921 roku konstytucyjnie je potwierdzono oraz rozszerzono o dostęp do urzędów publicznych na równi z mężczyznami (Hannam 2010, s. 189-201).

Zmiana społecznej sytuacji kobiet odbywała się z dala od murów Kościoła. Choć Jezus wprowadził wiele rewolucji w traktowaniu kobiet ${ }^{4}$, a za czasów św. Pawła pełniły one ważne funkcje w społecznościach chrześcijańskich (Dobrowolska 2015), to w historii Kościoła dość szybko ich rola uległa ponownej degradacji. Można tu przywołać przykłady Ojców Kościoła, jak św. Augustyn, który pisał: „Jest to naturalny porządek rzeczy wśród ludzi, że kobiety usługują swoim małżonkom,

3 W innych krajach: Wielka Brytania i Irlandia Północna (1928), Francja (1944), Włochy (1946), Szwajcaria (1971).

4 Jak choćby fakt, że nie będąc apostołkami, podążały za nim jako uczennice (Pismo Święte Starego i Nowego Testamentu). 
a dzieci rodzicom, gdyż sprawiedliwe jest, by niższe służyło wyższemu” (cyt. za: Wjingaards Institude for Catholic Research 2018).

Przez wieki równość kobiet wobec mężczyzn, zakładana w Kościele, dotyczyła tylko poziomu łaski i zbawienia, nie miała natomiast odniesienia do porządku doczesnego. Na ziemi kobieta miała być podporządkowana mężczyźnie (Adamiak 2011). Radykalnie zakwestionował to dopiero Sobór Watykański II (1962-1965).

Przed wspomnianym Soborem Kościół ostro reagował na społeczną zmianę roli kobiety. Leon XIII w rozdziale 33 encykliki Rerum Novarum pisał, że naturalnym miejscem kobiety nie jest życie zawodowe, ale domowe. Sam proces emancypacji kobiet krytykował inny papież - Pius XI w wydanej w 1930 roku encyklice Casti connubi. Podobne poglądy wyrażał jego następca Pius XII w serii katechez o małżeństwie (Pius XII 2009, s. 180). Dla Piusa XII po prostu nie do pomyślenia było, aby małżeństwo mogło być instytucją partnerską. Rola kobiety została więc sprowadzona wyłącznie do zarządzania domem i opieki nad dziećmi (Pius XII 2009, s. 172). Procesy emancypacyjne były więc jednoznacznie odrzucone, upatrywano w nich zagrożenia dla instytucji rodziny oraz pewnego rodzaju zamachu na naturalny porządek rzeczy, jakim jest patriarchalny układ w małżeństwie.

Podczas gdy stosunek Kościoła do zmiany sytuacji społecznej kobiet pozostawał sceptyczny, na gruncie feminizmu „drugiej fali” rodziły się nowe postulaty. Feministki dostrzegły, że prawa polityczne były niewystarczające, podczas gdy realia społeczne pozostawały nienaruszone. Od momentu wydania w 1949 roku książki Simone de Beauvoir Druga płeć druga fala domagała się realnej zmiany sytuacji społecznej kobiet (de Beauvoir 2007). W połowie lat 6o. kobiety zaczęły grupować się w nowe organizacje, których celem było poprawienie własnego statusu: National Organization for Women (NOW), The National Women Political Caucus (NWPC) i Women Equality Action League (Putnam Tong 1992, s. 35). Lata 6o. i 7o. były dla ruchu feministycznego także okresem „budzenia świadomości” zachęcano kobiety do grupowania się, opowiadania o własnych doświadczeniach, uświadamiania sobie własnego położenia (Putnam Tong 1992).

Kluczowy dla feminizmu drugiej fali podział między sferą prywatną (kobiecą) a publiczną (męską) zmuszał do uznania za Kate Millet, że „prywatne jest polityczne" (Mizielińska 2004, s. 100). To, co uważano za osobiste, niepodlegające dyskusji - czyli ciało, seksualność, związki, relacje w rodzinie - jest w rzeczywistości kreowane przez politykę i społeczeństwo. Postulowano, aby to, co było dotąd prywatne, stało się publiczne, tj. stało się przedmiotem powszechnej debaty, budzenia świadomości i negocjowania swojego charakteru (Hannam 2010, s. 152-153). Zdaniem Adrienne Rich, kultura patriarchalna wypacza doświadczenie macierzyństwa, czyniąc z kobiet seksualne niewolnice mężczyzn. Przyczyną takiej sytuacji jest ich zależność ekonomiczna od mężczyzn (Mizielińska 2004, s. 100-101). Betty Friedan w wydanej w 1963 roku Mistyce kobiecości opisywała sytuację białych kobiet z klasy średniej, które cały swój czas spędzały na pracach domowych, nie mając szans na rozwój i realizację zawodową. Ruch feministyczny postulował np. 
zniesienie dyskryminacji w miejscu pracy, pensję za prace domowe, poszerzenie możliwości opieki nad dzieckiem, informacje o środkach antykoncepcyjnych oraz prawo do aborcji.

Echo zmiany społecznej dotarło również do wież Kościoła, powoli rozbudzając zmianę podejścia do emancypacji kobiet. Zapoczątkowała ją encyklika Jana XXIII Pacem in terris (1963), gdzie emancypacja kobiet została odczytana jako znak czasu: „Udział kobiet w życiu publicznym jest już faktem dokonanym i oczywistym” pisał papież. Sobór Watykański II w konstytucji Gaudium et spes (1965) stwierdził: „Należy jednak przezwyciężyć i usuwać wszelką formę dyskryminacji odnośnie do podstawowych praw osoby ludzkiej, czy to dyskryminacji społecznej, czy kulturalnej, czy też ze względu na płeć, rasę, kolor skóry, pozycję społeczną, język lub religię, ponieważ sprzeciwia się ona zamysłowi Bożemu" (Sobór Watykański II..., 1967, s. 558). Jednocześnie Paweł VI wspomina w adhortacji Marialis Cultus (1974) o słusznej zmianie sytuacji kobiety: „prawa i postęp obyczajów słusznie przyznają jej [kobiecie] równość z mężem i władzę w kierowaniu życiem rodzinnym [...]. Kobieta dzisiejsza, która słusznie chce mieć udział w decyzjach społeczeństwa, z największą radością ducha będzie przypatrywać się Maryi” (Paweł VI 1974, pkt 34-37). Kościół dostrzegł niesprawiedliwość wiążącą się z sytuacją kobiet. Szczególnie ważne jest uznanie, że według zamysłu Bożego żadnej osoby nie można dyskryminować ze względu na płeć. Oznacza to, że w historii Kościoła, a nawet w Biblii znajdziemy wiele przykładów działań, które przeczyły „zamysłowi Bożemu”. Myśl tę rozwinie w swojej antropologii Jan Paweł II, przepraszając wszystkie kobiety, jeśli owa dyskryminacja spotkała je ze strony Kościoła (Adamiak 1999).

Zmiana nastawienia do kobiet znalazła swój wyraz w dopuszczeniu ich do obrad trzeciej sesji Soboru Watykańskiego II, co wcześniej było niemożliwe. Pod koniec posiedzenia wśród 40 przedstawicieli laikatu było 17 kobiet (Makowski 2007, s. 11-12). Obowiązujący obecnie Kodeks Prawa Kanonicznego (1983) dopuszcza kobiety do wielu funkcji, które wcześniej były dla nich niedostępne. Prawna zmiana nastawienia nie odnajduje jednak swojego odbicia w praktyce, gdyż pomimo legalistycznej możliwości, droga do wielu funkcji wciąż pozostaje dla kobiet zamknięta (Chołodniuk 2008, s. 91-103).

Papieże Jan XXIII, Paweł VI i Jan Paweł I ${ }^{5}$ prezentowali odmiennie niż ich poprzednicy nastawienie do kwestii kobiecej. Jednak najszerzej opracował to zagadnienie Jan Paweł II. Jako pierwszy spośród papieży poświęcił kobietom osobny dokument, list apostolski Mulieris dignitatem (1988). Kwestię kobiecą przedstawił także w wielu innych tekstach ${ }^{6}$.

5 Pomimo krótkiego pontyfikatu Jan Paweł I mówił w przemówieniu z 10 września 1978 roku: „Bóg jest naszym Ojcem, więcej - jest dla nasz także Matką”, odnosząc się tym samym w pozytywny sposób do fundamentalnych założeń teologii feministycznej (1978).

6 Najważniejsze to: encyklika Familiaris consortio (pkt 22-24), adhortacja Christifedeles laici (pkt 49-52), encyklika Redemptoris mater (pkt 46), encyklika Evangelium vitae (pkt 99), adhortacja 
Jan Paweł II rozwinął koncepcję tzw. teologii ciała. Poszukiwał na jej gruncie odpowiedzi na pytania o sens płciowości ludzkiej oraz jej biblijne znaczenie. Najważniejszym elementem owej antropologii jest założenie, że człowiek odnajduje swoją tożsamość poprzez spotkanie z Innym - mężczyzna i kobieta poznają sens swojej płciowości przez wzajemność, która, zdaniem Papieża, jest komplementarna. Struktura ciała nie jest przypadkowa - odzwierciedla powołanie człowieka: „Płeć stanowi nie tylko o somatycznej indywidualności człowieka, ale równocześnie określa jego osobową tożsamość i zarazem osobową konkretność" (Jan Paweł II 1980). Płci przypisuje się więc ogromne znaczenie - jest konstytutywna dla specyfiki człowieka. „Osobowe zasoby kobiecości na pewno nie są mniejsze od zasobów męskości - są tylko inne" (Jan Paweł II 1980). Zdaniem Jana Pawła II kobiety szczególnie spełniają się jako osoby w dwóch wymiarach: macierzyństwie i dziewictwie. O pierwszym z tych wymiarów pisze: „Analiza naukowa w całej pełni potwierdza fakt, że sama konstytucja cielesna kobiety oraz jej organizm zawierają w sobie naturalną dyspozycję do macierzyństwa, do poczęcia, brzemienności i urodzenia dziecka jako następstwa małżeńskiego zjednoczenia z mężczyzną. Odpowiada to zarazem psychofizycznej strukturze kobiety" (Jan Paweł II 1988).

Podczas gdy Jan Paweł II rozwijał swoją antropologię na gruncie feminizmu wiele dotychczasowych postulatów zostało podważonych i przekonstruowanych. Można wspomnieć choćby bell hooks czy Judith Butler, które wykazały, że „druga fala" wykluczyła doświadczenia wielu kobiet, a mówienie o jednym podmiocie feminizmu zawsze przenosi poza nawias niektóre kobiety. Nauczanie Jana Pawła II nie doczekało się jednakowoż rewizji czy aktualizacji ze strony kolejnych papieży. Choć możemy mówić o kolejnych odmianach falach feminizmu lub też epoce postfeminizmu, na gruncie katolickim działania emancypacyjne pozostają wciąż wywrotowe. Wspomnieć tu należy kwestię teologii feministycznej, walki o kapłaństwo kobiet lub inne formy dekonstrukcji obowiązującego modelu, które nadal pozostają działaniami peryferyjnymi.

\section{Święta Tekla - inspiracja dla edukacji antydyskryminacyjnej we wczesnym chrześcijaństwie}

Święta Tekla jest postacią praktycznie nieznaną współczesnemu katolicyzmowi. Do promocji jej osoby w Polsce w znaczący sposób przyczyniła się Zuzanna Radzik, biblistka, feministka, naukowiec - prowadząc warsztaty dotyczące kobiet wczesnego chrześcijaństwa podczas Slot Art Festiwal w Lubiążu w 2017 roku, a następnie podjęła ten temat w swojej publikacji pt. Emancypantki. Kobiety, które zbudowały Kościół (Radzik 2018). Zarówno warsztat, jak i książka oparte są na fragmentach

Via consecrata (pkt 57-58) oraz wiele listów i katechez, szczególnie zbiór Mężczyzną i niewiastą stworzył ich oraz list do kobiet w związku z IV Międzynarodową Konferencją ONZ (1995) (Filipak 2018). 
Nowego Testamentu, apokryfach i innych tekstach źródłowych. Pośród wielu innych żywotów męczennic, apostołek, diakonis, historia o pięknej młodej kobiecie z Ikonium wywiera na czytelniku ogromne wrażenie. Była to kobieta niezwykłej urody, zaręczona z patrycjuszem, którą ujęło nauczanie św. Pawła. Podsłuchiwała go przez okno, gdy nauczał w pobliskim domu - pod wpływem jego nauki przestała jeść, pić i rozmawiać z bliskimi. Przerażony jej zachowaniem narzeczony, Tamyris, wraz z tłumem postawił Pawła przed gubernatorem, a następnie wtrącił do więzienia. Tekla wymknęła się w nocy, przekupując strażnika weszła do celi Pawła, gdzie do rana przysłuchiwała się jego nauce. Rano wraz z nim została postawiona przed sądem i skazana na spalenie na stosie. Wygnany z miasta Paweł pościł w jej intencji, gdy ona w cudowny sposób została ocalona przed śmiercią - nie dotykał jej płonący ogień, a Bóg zesłał deszcz, który zgasił stos. Po tym wydarzeniu Tekla udała się z Pawłem do Antiochii, gdzie napotykała Aleksandra - kolejnego mężczyznę, który chciał wziąć ją za żonę. Gdy mu odmówiła i jednocześnie weszła z nim w konflikt, znowu stanęła przed sądem i została skazana na rozszarpanie przez dzikie zwierzęta. W cudowny sposób została obroniona przez lwice. Podczas tego wydarzenia Tekla sama ochrzciła się w dole pełnym wody, który znajdował się na arenie. Potem przez kilkadziesiąt lat nauczała, ewangelizowała, dokonywała cudów, założyła wspólnotę i pełniła de facto funkcje apostolskie (Dzieje Pawła i Tekli 1991). Nazywana jest pierwszą dziewicą-męczennicą (Internetowa Liturgia Godzin 2014). Zupełnie nie wiadomo, dlaczego nie zginęła męczeńsko - przecież już przed nią kobiety chrześcijanki poddawano torturom na arenie. Co więcej - apokryficzne źródła mówią o tym, że wcale nie zmarła: kiedy po raz kolejny banda mężczyzn przypuściła atak na Teklę, już wtedy staruszkę (według źródeł żyła około 8o lat wiek imponujący jak na owe czasy), ziemia rozstąpiła się i kobieta znikła im sprzed oczu (Radzik 2018, s. 78-100).

W literaturze nurtu feminizmu katolickiego nazywana jest „świętą transwestytką" (Stopera Freyhauf 2013). Oczywiście termin ten jest mylący i nie popieramy jego użycia w tym kontekście - obarczony jest wszak swoistą treścią przywodzącą na myśl Queer Festivals. Kobiety wczesnego chrześcijaństwa często decydowały się na ścięcie włosów i męski ubiór, nierzadko była to droga do wstąpienia do męskiego klasztoru, bycia dopuszczonym do studiowania świętych ksiąg i służby. Takie przebranie, łącznie ze zmianą imienia, nie było rzadkością (Radzik 2018, s. 163-192). Tekla decydowała się na męski ubiór zapewnie z powyższych powodów, lecz także z uwagi na swoją legendarną urodę i częste ataki ze strony mężczyzn, nie

7 Nawet definicja słownikowa nie wydaje się przystawać do znaczenia, w którym termin ten używany jest do opisu świętych kobiet upodabniających się do mężczyzn, aby np. prowadzić życie w zakonach męskich. „Transwestyta - zaburzenie identyfikacji z własną płcią polegające na upodabnianiu się w sposobie bycia i ubierania się do osób płci przeciwnej” (Słownik języka polskiego, dostępny na: https://sjp.pwn.pl/slowniki/transwestyta.html (otwarto: 26.10.2018). 
oznacza to jednak zmiany płci, nawet symbolicznej. Święta nie zmieniła imienia (Radzik 2018, s. 185) ${ }^{8}$, zaś ikonografia przedstawia ją w szatach kobiecych.

W pierwszych wiekach chrześcijaństwa imię Tekla było w Egipcie drugim co do popularności po imieniu Marii (Radzik 2018, s. 97). Kult św. Tekli rozciągał się od północnego Sudanu (Żurawski 2016), przez Egipt, Syrię, po Turcję, Cypr, Włochy i inne kraje basenu Morza Śródziemnego. Święta Tekla miała swoje sanktuaria: w Seleucji, w Antiochii, w Dalisandos (Izauria), w Selinuncie, w Konstantynopolu, w Aeca (Apulia) i w Mediolanie. Już sama liczba sanktuariów i ich rozmieszczenie dowodzą powszechności jej czci (Internetowa Liturgia Godzin 2014). W trakcie podróży po Cyprze wciąż można napotkać na ślady kultu świętej, choć poza monastyrem kobiecym jej imienia, znajdującym się w okolicach Larnaki (Monastery of Saint Thekla the Healer, Mosfiloti, Cypr) miejsca kultu św. Tekli są mniej znane, co wymaga wysiłku w ich odnalezienie. Są nimi np. jaskinia przy samym morzu (Ajia Napa, Cypr), maleńka piwniczna cerkiewka ukryta w ciągu magazynów na tyłach mikrorestauracji (Limasol, Cypr). Miejsce wieloletniej pracy świętej i sanktuarium jej imienia znajdują się granicach muzułmańskiej Turcji. Jak wiemy, święta osiadła w Seleukei, w Cylicji (rejon obecnej muzułmańskiej Turcji). Warto przywołać tu informacje turystyczne z Internetu: Google Maps nic nie pokazuje, ponieważ miasto zamieszkiwane przez św. Teklę nie istnieje, na polskich stronach internetowych możemy zaś znaleźć wiele atrakcji z tamtych czasów - od wodospadów po ruiny świątyni Apolina - a o Tekli źródła internetowe milczą; podobnie nie znajdziemy o niej wzmianki w opisie miejscowości Seleukei na stronie anglojęzycznej Wikipedii ${ }^{9}$. Sanktuarium Tekli znajduje się w innym miejscu - w Meriamrik (Kristensen 2016).

W artykule stanowiącym refleksyjną opowieść z podróży George H. Forsyth opisuje monumentalny budynek sanktuarium, który jednak już w latach 50. popadł w ruinę (Forsyth 1957). Jak często zdarza się w przypadku tej świętej, doskonale zachowane są podziemne miejsca jej kultu. Metaforyczne odczytanie tego faktu, miejsc w podziemiach, ukrytych przed światem, jest ciekawym wątkiem opowieści.

Zaginione ślady po św. Tekli w sposób symboliczny ukazują sytuację kobiet, która nie odpowiada konserwatywnej i tradycyjnej roli kobiety. W poznawaniu i promowaniu jej historii widzimy ogromny potencjał - zarówno edukacyjny, jak i emancypacyjny. Przez wieki herstorie takie jak ta zacierane były przez obowiązujący dyskurs poddaństwa i posłuszeństwa kobiet. Konieczne jest powracanie do źródeł wczesnochrześcijańskich i wskazywanie na to, że emancypacja kobiet nie jest

8 Pośród tak nazywanych świętych znajdujemy np. św. Anastazję żyjącą jako Anastasios, św. Apolinarię - jako Doroteos, Eugenię - jako Eugenios, a Maria egipska zasłynęła jako mnich Marinos.

9 Na wakacje: Seleukeja (Seleukeia), Turcja, dostępny na: https://www.turcja.com.pl/seleukeja-seleukeia.xml (otwarto: 26.10.2018), Seleucia (Pamphylia), dostępny na: https://en.wikipedia. org/wiki/Seleucia_(Pamphylia) (otwarto: 26.10.2018). 
wymysłem nowoczesności, ale mocnym argumentem w dyskusji nad oddawaniem kobietom głosu i władzy w Kościele.

\section{Na zakończenie}

Zamiast zakończenia przywołać chcemy raz jeszcze Assmanna, z jego rozumieniem ważkości przywoływania pamięci i badań nad nią: „dla historyka pamięci «prawda» określonego wspomnienia nie leży w jego «faktyczności», lecz raczej «aktualności». Wydarzenia zazwyczaj ulegają zapomnieniu, o ile nie przeżyją w pamięci zbiorowej. To samo dotyczy podstawowych rozróżnień znaczeniowych. Nie ma w historii znaczenia, o ile rozróżnienia te nie są pamiętane. Przyczyną tego «przeżywania» jest ciągła istotność wydarzeń. Istotność ma swoje źródło nie w historycznej przeszłości, lecz w nieustannie zmieniającej się teraźniejszości, w której wydarzenia są pamiętane jako znaczące fakty" (Assmann 2018, s. 424-425)

Historia św. Tekli przedstawiona została w sposób subiektywny powyżej. Obraz świętej jest bardzo sugestywny: uparcie podążała ona za św. Pawłem, ryzykowała swą godność i życie dla chrztu; odrzuciła bezpieczne życie u boku majętnego męża, sprzeciwiła się rodzinie, trafiła na arenę tylko dlatego, że postanowiła samodzielnie, wbrew wszystkim, swoim głosem i całym życiem zamanifestować wiarę w Jezusa zmartwychwstałego; całe swe długie życie poświęciła budowaniu Kościoła. Jeśli otaczano ją „szklanym kloszem”, to z pewnością robiła wszystko, aby go stłuc na drobne kawałki. Nie tylko doświadczała świata zewnętrznego (zarówno w wymiarze fizycznym, jak i duchowym), lecz także uczyniła swój głos słyszalnym w całym basenie Morza Śródziemnego. Uważamy, że poznawanie takich herstorii, namysł i dyskusje nad nimi, to strategia edukacyjna, która ma wielki potencjał i może stanowić odpowiedź na oczywistą, skądinąd, potrzebę. Wszak: „prawo do tego, by stanąć i zabrać głos, jest niezbędne do przetrwania, niezbędne, by cieszyć się wolnością i godnością" (Solnit 2017, s. 22):

\section{Bibliografia}

Adamiak E. (1999). Milcząca obecność. O roli kobiety w Kościele. Warszawa: Więź. Adamiak E. (2011). Panowanie mężczyzny jest złe, rozmawiała Katarzyna Wiśniewska. „Gazeta Wyborcza”, 27.04.2011. Dodatek „Wysokie obcasy”, dostępny na: http:// www.wysokieobcasy.pl/wysokie-obcasy/1,96856,9501693,Panowanie_mezczyzny_jest_zle.html?disableRedirects=true (otwarto: 26.10.2018).

Assmann J. (2018). Mnemohistoria i konstruowanie Egiptu. W: P. Majewski, M. Napiórkowski (red.). Antropologie pamięci: zagadnienia i wybór tekstów. Warszawa Wydawnictwa Uniwersytetu Warszawskiego, s. 421-430.

Augustyn, Rozważania nad siedmioksięgiem, ks. I, par. 153. W: Wjingaards Institude for Catholic Research, Kobiety uważano za niższe istoty, dostępny na: http:// www.womenpriests.org/pl/traditio/inferior.asp (otwarto: 26.10.2018). 
de Beauvoir S. (2007). Druga płeć. Mycielska G., Leśniewska M. (tłum.). Warszawa: Czarna Owca.

Chołodniuk J. (2008). Miejsce kobiet w Kościele rzymskokatolickim w Polce-sytuacja prawna. W: Adamiak E., Chrząstowska M. (red.). Godzina Kobiet? Recepcja nauczania Kościoła Rzymskokatolickiego o kobietach w Polsce w latach 19782005. Poznań: Wydawnictwo Naukowe Uniwersytetu im. Adama Mickiewicza, s. $91-103$.

Dobrowolska A. (2015). Czy św. Paweł był feministą? „Kontakt”, nr 147, dostępny na: http://magazynkontakt.pl/czy-sw-pawel-byl-feminista.html (otwarto: 26.10.2018).

Dzieje Pawła i Tekli. Starowieyski M. (tłum.). „Ruch Biblijny i Liturgiczny”, t. 44, nr 4-6, Warszawa 1991, dostępny na: https://rbl.ptt.net.pl/index.php/RBL/article/ view/995 (otwarto: 10.02.2019).

Forsyth G. H. (1957). Architectural Notes on a Trip Through Cilicia. „Dumbarton Oaks Papers”, vol. 11, dostępny na: https://www.jstor.org/stable/1291108?newacc ount=true\&read-now=1\&seq=14\#page_scan_tab_contents (otwarto: 26.10.2018).

Hannam J. (2010) Feminizm, Kaflińska A. (tłum.). Poznań: Zysk i S-ka.

Jan Paweł I, Przemówienie z 10 września 1978, dostępny na: http://w2.vatican.va/ content/john-paul-i/en/angelus/documents/hf_jp-i_ang_10091978.html (otwarto: 26.10.2018).

Jan Paweł II. (1981). Familiaris consortio, dostępny na: https://opoka.org.pl/ biblioteka/W/WP/jan_pawel_ii/adhortacje/familiaris.html (otwarto: 26.10.2018).

Jan Paweł II. (1980). Mężczyzną i niewiastą stworzył ich. Watykan: Libreria Editrice Vaticana.

Jan Paweł II. (1988). Mulieris dignitatem, dostępny na: https://opoka.org.pl/ biblioteka/W/WP/jan_pawel_ii/listy/mulieris.html (otwarto: 26.10.2018).

Jan Paweł II. (1994). Szerokie pole do działań kobiety w Kościele - audiencja generalna z 13 lipca 1994 r. „L'Osservatore Romano”, t. 15, nr 8, s. 24.

Jan XXIII. (1963). Pacem in terris, dostępny na: http://www.nonpossumus.pl/encykliki/Jan_XXIII/pacem_in_terris/I.php (otwarto: 26.10.2018).

Kodeks Prawa Kanonicznego, dostępny na: http://www.trybunal.mkw.pl/Kodeks\%20 Prawa\%2oKanonicznego.pdf (otwarto: 26.10.2018).

Kristensen T. M. (2016). Landscape, Space, and Presence in the Cult of Thekla at Meriamlik. "Journal of Early Christian Studies”, nr 24 (2), dostępny na: http:// projects.au.dk/fileadmin/projects/Sacredtravel/JECS-Vol24-2-2016-articleTMyrup-Kristensen.pdf (otwarto: 26.10.2018).

Makowski J. (2007). Kobiety ucza Kościót. Warszawa: WAB.

Mizielińska J. (2004). (De)konstrukcje kobiecości. Podmiot feminizmu a problem wykluczenia. Gdańsk: Wydawnictwo słowo/obraz terytoria.

O kobiecie, oprac. M. Filipiak, dostępny na: http://www.kul.pl/o-kobiecie,art_1769. html (otwarto: 26.10.2018).

Na wakacje: Seleukeja (Seleukeia), Turcja, dostępny na: https://www.turcja.com. $\mathrm{pl} /$ seleukeja-seleukeia.xml (otwarto: 26.10.2018). 
Paweł VI, Marialis cultus, dostępny na: http://www.duchprawdy.com/pawel_vi_adhortacja_marialis_cultus_1974.htm (otwarto: 26.10.2018).

Pismo Święte Starego i Nowego Testamentu. Biblia Tysiąclecia (2013). Warszawa: Pallottinum.

Pius XI. (1930). Casti connubi. Encyklika o małżeństwie chrześcijańskim, dostępny na: http://www.nonpossumus.pl/encykliki/Pius_XI/casti_connubii/index.php (otwarto: 26.10.2018).

Pius XII. (2009). Małżeństwo na zawsze. Stoppa J. (tłum.). Sandomierz: Wydawnictwo Diecezjalne.

Putnam Tong R. (1992). Myśl feministyczna. Wprowadzenie. Mikos J., Umińska B. (tłum.). Warszawa: PWN.

Radzik Z. (2018) Emancypantki. Kobiety, które zbudowały Kościół. Kraków: WAM. Seleucia (Pamphylia), dostępny na: https://en.wikipedia.org/wiki/Seleucia_ (Pamphylia) (otwarto: 26.10.2018).

Sobór Watykański II. Konstytucje, dekrety, deklaracje (1967). Kraków: Pallottinum. Solnit S. (2017). Mężczyźni objaśniają mi świat, Dzierzgowska A. (tłum.). Kraków: Karakter.

Stopera Freyhauf M., St. Thecla: Transvestite Saint and Woman Apostle, dostępny na: https://feminismandreligion.com/2013/02/21/st-thecla-transvestite-saint-and-woman-apostle-by-michele-stopera-freyhauf (otwarto: 26.10.2018).

Święta Tekla, dziewica i męczennica, Internetowa Liturgia Godzin, dostępny na: https://www.brewiarz.pl/czytelnia/swieci/o9-24d.php3 (otwarto: 26.10.2018).

M.R. James, The Acts of Paul/and Thecla, dostępny na: http://www.scriptural-truth.com/PDF_Apocrypha/The\%2oActs\%20of\%2oPaul\%20and\%20 Thecla.pdf?fbclid=IwAR34KJ_QjghMkacrrcKN8JwbOPNsAx8FzX6cjs18O8eFkQQx48hv5ZloyE; link skrócony: http://bit.ly/fp2019-2-2 (otwarto: 26.10.2018).

Women's Ordination Conference. A Voice for Women's Equality in the Catholic Church, dostępny na: https://www.womensordination.org (otwarto: 26.10.2018).

Żurawski B. (2016). The Altar Casket with a Representation of St Thecla ad bestias from the Vicinity of the St Menas Church in Selib (Northern Sudan). „Études et Travaux", vol. 29, dostępny na: http://cejsh.icm.edu.pl/cejsh/element/bwmeta1. element.desklight-8eaf1d2b-ea5f-4b65-aoao-14cc9ee4a5e8/c/14_Zurawski.pdf (otwarto: 26.10.2018).

\section{BETWEEN CATHOLIC CHURCH'S TEACHING AND FEMINISM - EDUCATIONAL POTENTIAL OF HERSTORY BASED ON SAINT THECLA'S LIFE}

Abstact: The article outlines the issue of the dialogue between the Catholic Church's teaching and broadly understood feminism as a context for the original proposal of an 
educational strategy stemming from history (herstory) of the first centuries of Christianity. The exemplification of the contemporarily little-known saint (Saint Thecla) serves as a reinforcement for the concept of education on gender equality resulting directly from the act of creation, strengthened in the act of salvation and, as such, present in the teaching of the Church. Equal before God, women deserve equal rights in seeking paths to get to know him and serve him. Contemporary trends of the women's liberation movement are often perceived as hostile towards the teachings of the Church. Meanwhile, the history of the early Christian ages indicates the respect women were given, their undeniable role in building community, martyrdom, determination, wisdom and beauty. Adopting such an educational strategy is akin to "removing a lampshade" (Sylvia Plath's metaphor), while learning the herstory of women who built Christianity can serve as an inspiration for personal (not only spiritual) development of women in the Catholic Church.

Keywords: herstory; feminism; emancipation; discourse; narration; spoken history.

Hanna Achremowicz - absolwentka filozofii, pedagogiki i oligofrenopedagogiki. Od 2012 roku realizowała liczne projekty edukacyjne i badawcze, związane z obszarem wykluczenia społecznego, bezdomności, ekologii, edukacji patriotycznej, streetworkingu, muzealnictwa i doświadczenia macierzyństwa. W latach 2013-2016 pracowała w Towarzystwie Nasz Dom, opartym m.in. na założeniach pedagogicznych J. Korczaka, a w latach 2017-2018 jako pedagog specjalny w szkole podstawowej. Adres korespondencyjny: Stowarzyszenie Edukacji Krytycznej, ul. Legnicka 65, 54-206 Wrocław. Adres e-mailowy: hanna.ach@gmail.com.

Kamila Kamińska-Sztark - doktor nauk humanistycznych, od 2005 roku adiunkt w Instytucie Pedagogiki Uniwersytetu Wrocławskiego Zajmuje się pedagogiką miasta, szczególnie rewitalizacją, streetworkingiem, interesuje się sztuką ulicy. Prowadzi badania nad edukacją międzykulturową, pisze scenariusze zajęć, szkoli. Jest członkinią zarządu międzynarodowych organizacji naukowych: Discourse Power Resistance, University Network of European Capitals of Culture. Od 2016 roku pełni funkcję pełnomocnika rektora UWr ds. odpowiedzialności społecznej. Adres korespondencyjny: Instytut Pedagogiki Uniwersytetu Wrocławskiego, ul. Dawida 1, 50-527 Wrocław. Adres e-mailowy: kamila. kaminska@uwr.edu.pl. 